\title{
Morphology of young tillers of marandu palisadegrass arising in high or low canopy
}

\author{
Bruno Humberto Rezende Carvalho*1, Bruno Nascimento Segatto ${ }^{1}$, \\ Kathleen Alves Vasconcelos ${ }^{1}$, Gustavo Jordan da Silva Queiroz', \\ Jessica Abreu de Sá Medica ${ }^{1}$, Manoel Eduardo Rozalino Santos ${ }^{1}$
}

\begin{abstract}
Tillers study, even though reductionist, helps in understanding the pasture development, an important knowledge for decision making during the grazing management. So, this study evaluates changes in morphology of young tiller at two locations in the same pasture of Brachiaria brizantha cv. Marandu syn. Urochloa brizantha (marandu palisadegrass), one with plants of $25 \mathrm{~cm}$ and other with plants of $50 \mathrm{~cm}$ in height. The design was adopted in a randomized block design with four replications. The marandu palisadegrass was managed in alternate grazing, a mode of intermittent stocking, using cattle. The forage mass, as well as the number of reproductive tillers was higher in pasture site with $50 \mathrm{~cm}$, compared to that $25 \mathrm{~cm}$. The contrary response occurred to a number of vegetative tillers. The lengths of leaf and stem of young tillers were smaller in locations with $25 \mathrm{~cm}$, compared to $50 \mathrm{~cm}$. The numbers of live and dead leaves were not influenced by sward height. The larger mass of green leaves and stem per tiller was on site with $50 \mathrm{~cm}$ in relation to that $25 \mathrm{~cm}$. The same pattern was observed for the individual weight of tillers. The young tillers coming from small plants contained higher leaf/stem ratio, when compared to that arise from tall plants. In the same pasture, the young tillers and with the same development stage of $B$. brizantha cv. Marandu syn. U. brizantha cv. Marandu exhibit different morphologies depending on the plant height which they originate.
\end{abstract}

Keywords: Canopy height, Morphological composition, Phenotypic plasticity.

\section{RESUMO}

O estudo dos perfilhos, embora reducionista, auxilia na compreensão do desenvolvimento do pasto, um conhecimento importante para a tomada de decisão durante o manejo do pastejo. Desta forma, este trabalho foi realizado para avaliar as alterações na morfologia do perfilho jovem em dois locais do mesmo pasto de Brachiaria brizantha cv. Marandu syn. Urochloa brizantha cv. Marandu (capim-marandu), sendo um com plantas de $25 \mathrm{~cm}$ e o outro com plantas de $50 \mathrm{~cm}$ de altura. Adotou-se o delineamento em blocos casualizados com quatro repetições. O capimmarandu foi manejado em pastejo alternado, uma modalidade da lotação intermitente, utilizando bovinos. A massa de forragem, bem como o

\footnotetext{
${ }^{1}$ Faculdade de Medicina Veterinária da Universidade Federal de Uberlândia

* Autor para correspondência: Faculdade de Medicina Veterinária - FAMEV, Campus Glória - Bloco 1CCG, sala 211A, BR-050, KM 78, 38410-337, Uberlândia, MG, Brasil. brunohrc16@hotmail.com
} 
número de perfilhos reprodutivos foi maior no local do pasto com $50 \mathrm{~cm}$, em relação àquele com $25 \mathrm{~cm}$. Resposta contrária ocorreu com o número de perfilho vegetativo. Os comprimentos da lâmina foliar e do colmo dos perfilhos jovens foram menores nos locais com $25 \mathrm{~cm}$, em relação aos com $50 \mathrm{~cm}$. Os números de folhas vivas e mortas não foram influenciados pela altura do pasto. A maior massa de folhas vivas e de colmo por perfilho ocorreu no local com $50 \mathrm{~cm}$, em relação àquele com $25 \mathrm{~cm}$. O mesmo padrão de resposta foi observado para o peso individual dos perfilhos. Os perfilhos jovens oriundos de plantas baixas possuíram maior relação folha/colmo, quando comparado aos que surgiram de plantas altas. Em um mesmo pasto, os perfilhos jovens e com mesmo estágio de desenvolvimento de $B$. brizantha cv. Marandu syn. U. brizantha cv. Marandu apresentam morfologias diferentes, em função da altura da planta do qual se originam.

Palavras-chave: Altura do dossel, Composição morfológica, Plasticidade fenotípica.

\section{Introduction}

Among the forage grasses used in Brazil, Brachiaria brizantha cv. Marandu (marandu palisadegrass) is among the most used for livestock production in pastures. This grass has been well accepted by ranchers and, in recent years, occupies approximately 50 million hectares of Brazilian pastureland (JANK et al., 2014). Thus, studies that evaluate the morphology of this important forage resource are relevant for a better understanding of forage plant responses in the pasture.

Indeed, the knowledge of the biotic and abiotic phenomena that influence the pasture morphology is of paramount importance because the morphology or structure of the pasture, which corresponds to the distribution of the aerial parts of the plant in a community, determines changes in the canopy microclimate, with effects on the development of forage plants. In addition, the morphology of the forage plant also modifies the ingestive behavior patterns of grazing ruminants, with consequences on the consumption and performance of the animals (FONSECA et al., 2012). Therefore, morphological characteristics have been considered in studies on 
grazing management of tropical forage grasses (SBRISSIA et al., 2010; VILELA et al., 2013)

In this sense, the morphological evaluation of the tiller, although reductionist, characterizes in a detailed way the structural or morphological characteristics of the pasture, because the tillers constitute the modular units of growth and perenization of the pasture (VILELA et al., 2013). However, the evaluation of the morphology of tillers in a pasture is a complex task, due to the great variability of tillering categories in the same pasture, which presents tillers of various ages.

In fact, in a single monospecific grass, such as marandu palisadegrass, there are several types or categories of tillers, with different morphological characteristics (SANTOS et al., 2011). This fact is, at the same time, the cause and the consequence of the typical spatial variability of the vegetation in the tropical pastures, which can be characterized by the occurrence of forage plants with different heights in the horizontal plane of the pasture (SANTOS et al., 2014).

The changes in morphological characteristics of tillers are a way for the forage plant to adapt to the variations in the conditions of the environment in which it lives, a process called phenotypic plasticity. Thus, in the same pasture, the sites with plants of different heights generate distinct microclimates, which alters the morphology of the newly formed tiller.

One of the modifications that occur in the microclimate in locations with plants with variable heights in the same pasture concerns the light environment inside the canopy. This can modify the morphology of young tillers since light quantity and quality are determinants of tillering and tillering development (DEREGIBUS et al., 1983).

In young tillers with up to three live leaves, it is possible that the phenotypic plasticity, characterized by variations in morphological composition and organ size, is more intense, because the new tillers are 
more responsive to the medium stimuli (BULLOCK et al. al., 1994; PAIVA et al., 2012).

Thus, the present experiment was conducted with the objective of understanding how different heights of canopies in the same pasture influence the morphology of young tillers.

\section{Material and methods}

This work was conducted in an experimental area with Brachiaria brizantha cv. Marandu (marandu palisadegrass), belonging to the Faculty of Veterinary Medicine of the Federal University of Uberlândia, UberlândiaMG. The approximate geographical coordinates of the experiment site are $18^{\circ} 30^{\prime}$ south latitude and $47^{\circ} 50^{\prime}$ west longitude of Greenwich, and its altitude is $776 \mathrm{~m}$. The climate of the Uberlândia region, according to the classification of Köppen (1948), is of the type Cwa, tropical of altitude, with dry and dry winter, and dry and rainy seasons well defined.

Before the experiment, the pasture of marandu palisadegrass was managed in continuous stocking with cattle, and the pasture presented an average height of $40 \mathrm{~cm}$. Prior to the experiment, soil samples were also taken for analysis of the fertility level, in the $0-20 \mathrm{~cm}$ layer, with the following results: $\mathrm{pH}$ in $\mathrm{H}_{2} \mathrm{O}: 6,1$; $\mathrm{P}: 2.5$ (Mehlich-1) and $\mathrm{K}: 94 \mathrm{mg} / \mathrm{dm}^{3}$; $\mathrm{Ca}^{2+}$ : 3.1; $\mathrm{Mg}^{2+}: 1.3 ; \mathrm{Al}^{3+}: 0.0 \mathrm{cmol}_{\mathrm{c}} / \mathrm{dm}^{3}(\mathrm{KCl} 1 \mathrm{~mol} / \mathrm{L})$. Soil correction and fertilization of the experimental area were not performed.

After the marandu palisadegrass establishment, in 2000, it was managed under the alternating grazing regime, a mode of intermittent stocking with cattle. In this management, the animals remained in the pasture for periods of occupation and long rest and the like, of approximately 30 days.

The experimental area was subdivided, without fences, into four bands (experimental units). In May 2012, the structural characteristics of 
the young tillers of Brachiaria brizantha cv. Marandu were evaluated, according to the height of the plants in two sites of the same pasture. For this, in each band, two sites were evaluated, with plants of $25 \mathrm{~cm}$ and of 50 $\mathrm{cm}$ of height. The randomized block design, with four replications, was adopted.

For characterization of the evaluated sites, the numbers of vegetative and reproductive tillers, as well as the mass of forage were determined. Tiller population density was determined by counting the tillers contained within a frame of $25 \mathrm{~cm}$ by $50 \mathrm{~cm}$ at three sites representative of the evaluated heights. The live tiller that had the visible inflorescence were classified as reproductive, and the living ones that did not have the visible inflorescence were denominated of vegetative.

The forage mass was also determined in three sites with tall plants $(50 \mathrm{~cm})$ and three with low plants $(25 \mathrm{~cm})$. For that, all the tiller contained within a square of $0.25 \mathrm{~m}^{2}$ were collected close to the soil. Each sample was taken to the laboratory, weighed and placed in a greenhouse at $65^{\circ} \mathrm{C}$ for 72 hours when it was again weighed.

In each experimental unit, 50 young tillers were collected at each site evaluated. Tillers with a maximum of three fully expanded leaves were selected, which were cut close to the soil and taken to the laboratory. The following characteristics were evaluated: numbers of expanded leaves (with exposed ligule), in expansion (with ligule not yet exteriorized) and dead (more than $50 \%$ of its length in senescence); mean lengths of the expanded leaf blades (distance between the ligule and apex of leaf blade) and the leaf blades in expansion (from the ligule of more young and expanded leaf to the apex of the leaf blade), as well as the stem length (from the soil surface to the ligule of the expanded young leaf).

After the evaluation of the structural characteristics of the tillers, the samples were separated in live leaf blade, dead leaf blade, and stem. These subsamples were taken to the greenhouse at $65^{\circ} \mathrm{C}$ for $72 \mathrm{~h}$. From those data, 
the average weight and the morphological composition of the tillers were calculated.

The data were submitted to analysis of variance and compared by the $\mathrm{F}$ test, at the level of $5 \%$ probability of occurrence of the type I error

\section{Results and discussion}

The young tillers were harvested in the same pasture, but in places with quite different canopies (Figure 1). This was the objective with the present work: to evaluate plants in the same pasture with disparate morphologies, in order to verify the morphological modification of the tillers. In this sense, the high site was twice as large as the low site (Figure 1A), presented higher forage masses (Figure 1B), as well as a larger number of reproductive tillers (Figure 1D), however, it had fewer vegetative tillers (Figure 1C).

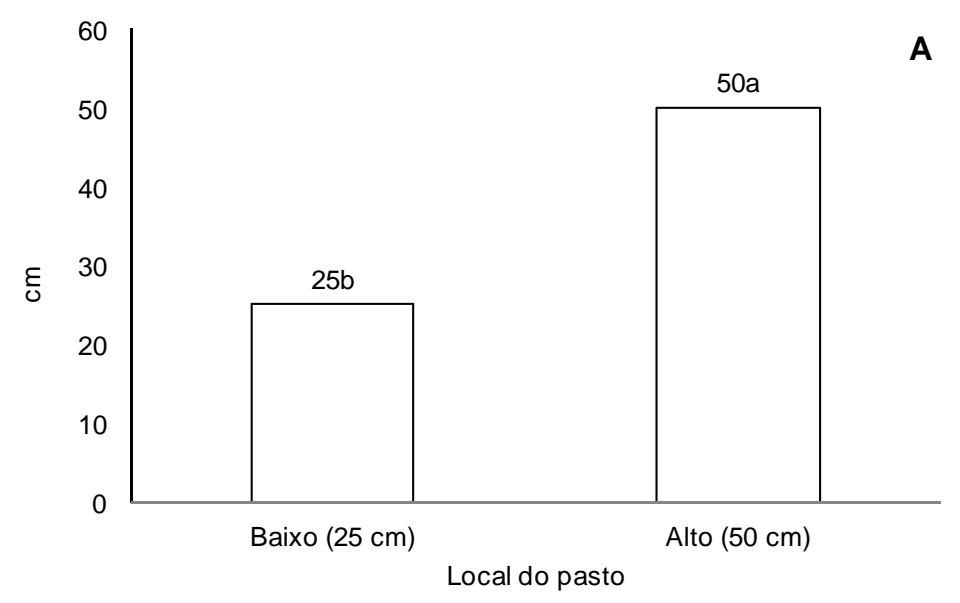



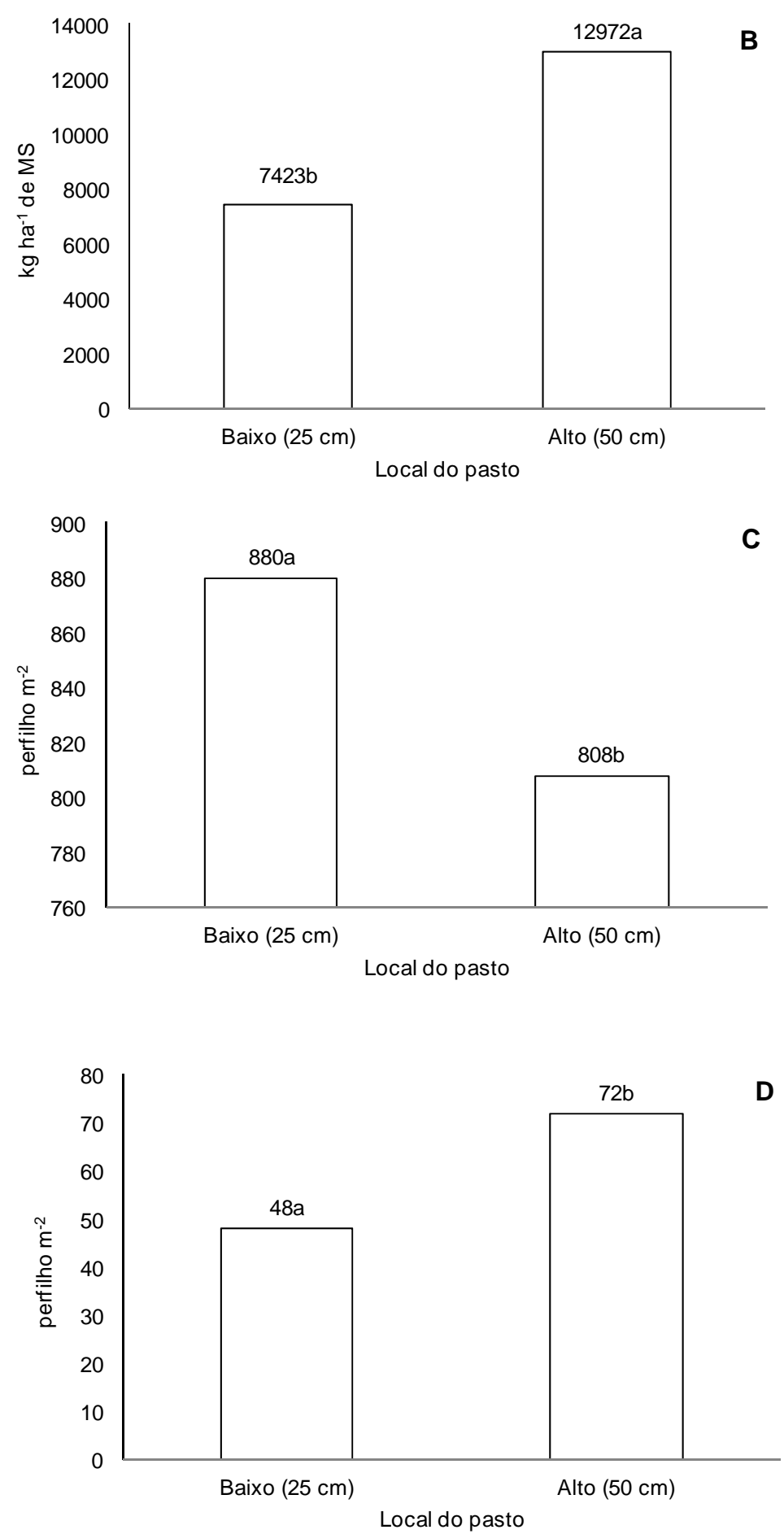

In each graph, means followed by the same letter did not differ by $\mathrm{F}$ test $(\mathrm{P}>0.05)$.

Figure 1. Characterization of the low and high sites in the same pasture with Brachiaria brizantha cv. Marandu: canopy height (A), forage mass (B), numbers of vegetative (C) and reproductive tillers (D). 
The large height difference of the plants (Figure 1A), in fact, permitted the coherent denomination of the evaluated sites: low site, with plants of an average height of $25 \mathrm{~cm}$, and high place, with plants of an average height of $50 \mathrm{~cm}$.

The variability of the heights of plants in the same pasture is a natural and inherent characteristic of any pasture, caused, among other factors, by the selective defoliation of the animals, as well as the different conditions of supply of trophic resources in the horizontal pasture, such as fertility of soil, water availability and distribution of ruminant excretions (SANTOS et al., 2014).

The highest forage mass was found at the high site rather than at the low site (Figure 1B), an expected response pattern, because the grass height may be used as an indirect measure of the pasture mass of tropical grasses, the relationship between these variables is, in general, linear and positive. This result is justified because in higher places the tillers are longer, possibly due to the occurrence of greater competition for light, which results in elongation of the stem to expose the young leaves in the upper part of the canopy where the light is more abundant (LARA And PEDREIRA, 2011). In addition, the longer tillers require a sturdy, more developed structural organ to support their higher weight, contributing to the greater forage mass at the high pasture site.

The vegetative tiller differs from the reproductive one due to the stage of development. In general, vegetative tillers are smaller in size, more numerous and have a better morphological composition and nutritive value when compared to reproductive tillers (VILELA et al., 2013). The highest density of vegetative tillers in the low site (Figure 1C) is due to the law of compensation between size and density of tiller (SBRISSIA et al., 2010), which shows that canopies with smaller heights have larger numbers of small tillers, while the sites with higher average height have a lower population density of large tillers. In fact, in low canopies, the higher incidence of light at the base of the plants stimulates tillering. On the other hand, in higher canopies, the greater shading at the base of the plant 
inhibits the development of basal buds in new tillers (SBRISSIA et al., 2010).

Compared to the vegetative tiller, an inverse response pattern occurred for the number of reproductive tillers, which was higher in the high site compared to the low one (Figure 1D). This result can be explained by the higher stage of development of the tiller in the high site, because the higher shading in the upper canopy causes a greater amount of assimilates to be allocated to the growth of existing tillers in detriment of new tillers (PEDREIRA et al., 2001). In addition, in the higher canopy, the animals probably performed grazing less frequently. With this, many tillers of this place did not have their development interrupted by grazing and, thus, they passed from the vegetative to the reproductive stage.

In relation to the length of the tiller organs (leaves in expansion, expanded leaves, and stem), all presented superior values in the high place of the pasture, when compared to the low place (Figure 2A). On the other hand, the numbers of the expanding, expanded or dead leaves ware did not vary between sites evaluated between the sites evaluated (Figure 2B).

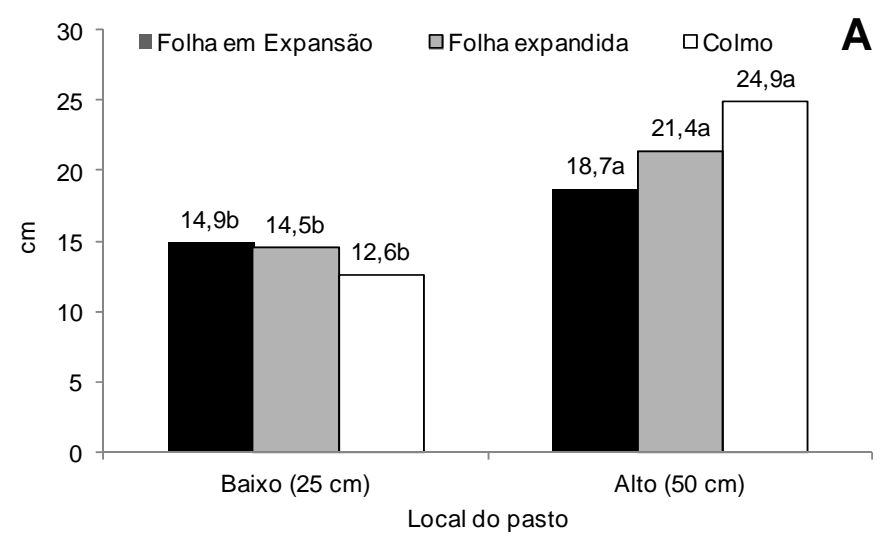




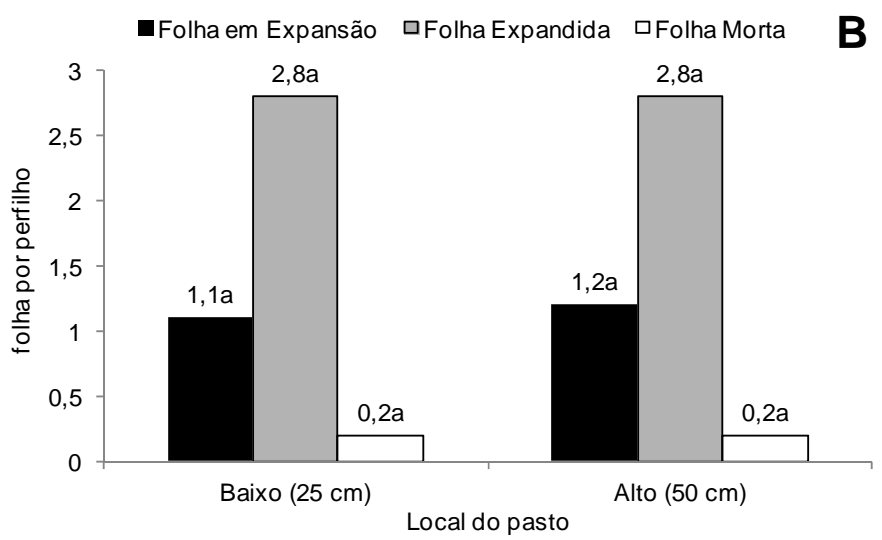

In each graph, means followed by the same letter did not differ by $\mathrm{F}$ test $(\mathrm{P}>0.05)$.

Figure 2. Length of the organs of the tiller (A) and a number of leaves per tiller (B) of a young tiller of Brachiaria brizantha cv. Marandu in low and high places of the same pasture.

The size of the stem was higher in the young tillers that developed in sites of the same grass with higher plants, in relation to the tiller of the sites with lower plants, probably due to the greater shading in the high place. In this condition, a change occurs in the morphology of the tiller, which accentuates the elongation of the stem to expose the new leaves in the upper region of the canopy, where the luminosity is greater. This is a typical morphological response of tropical forage grasses under shading conditions and has been reported for other species of tropical forage grasses (PEDREIRA et al., 2001).

The expanded and expanded leaf lengths are positively related to stem size. The longer the stem, the longer the period of cell division and leaf elongation, resulting in a longer leaf blade. In fact, in larger tillers, the youngest leaves carry a long course in the pseudostem to expose themselves. Thus, the distance traveled by the leaf from the point of connection with the meristem to the end of the pseudostem is larger, resulting in its longer length (SKINNER AND NELSON, 1995).

Leaf numbers were not influenced ( $\mathrm{P}>0.05$ ) by the sites evaluated (Figure 2B). This result is mainly due to the fact that these characteristics are quite stable, being usually a genotypic constant. However, a higher number of dead leaves were expected in the high site tiller due to the greater shading on the leaves in the lower canopy extract, which could result in lower rates of photosynthesis than respiration, with consequent loss of metabolic activity of the leaves, which would progress to its mortality. It is worth noting that, in this study, young tillers were evaluated, with at 
most three leaves fully expanded. At this stage of development, it is possible that most of the leaves were still very young, so that they did not exceed the life span of the leaves and, therefore, the values of a dead leaf by tillers were low and did not vary between the low and high (Figure 2B).

As regards the leaf and stem masses of the young tillers, these were higher $(\mathrm{P}<0.05)$ at the high site, compared to the low site; however, dead leaf mass did not vary among the studied sites (Figure 3B). The individual tiller weight was also higher in the high site than in the low site (Figure 3A).
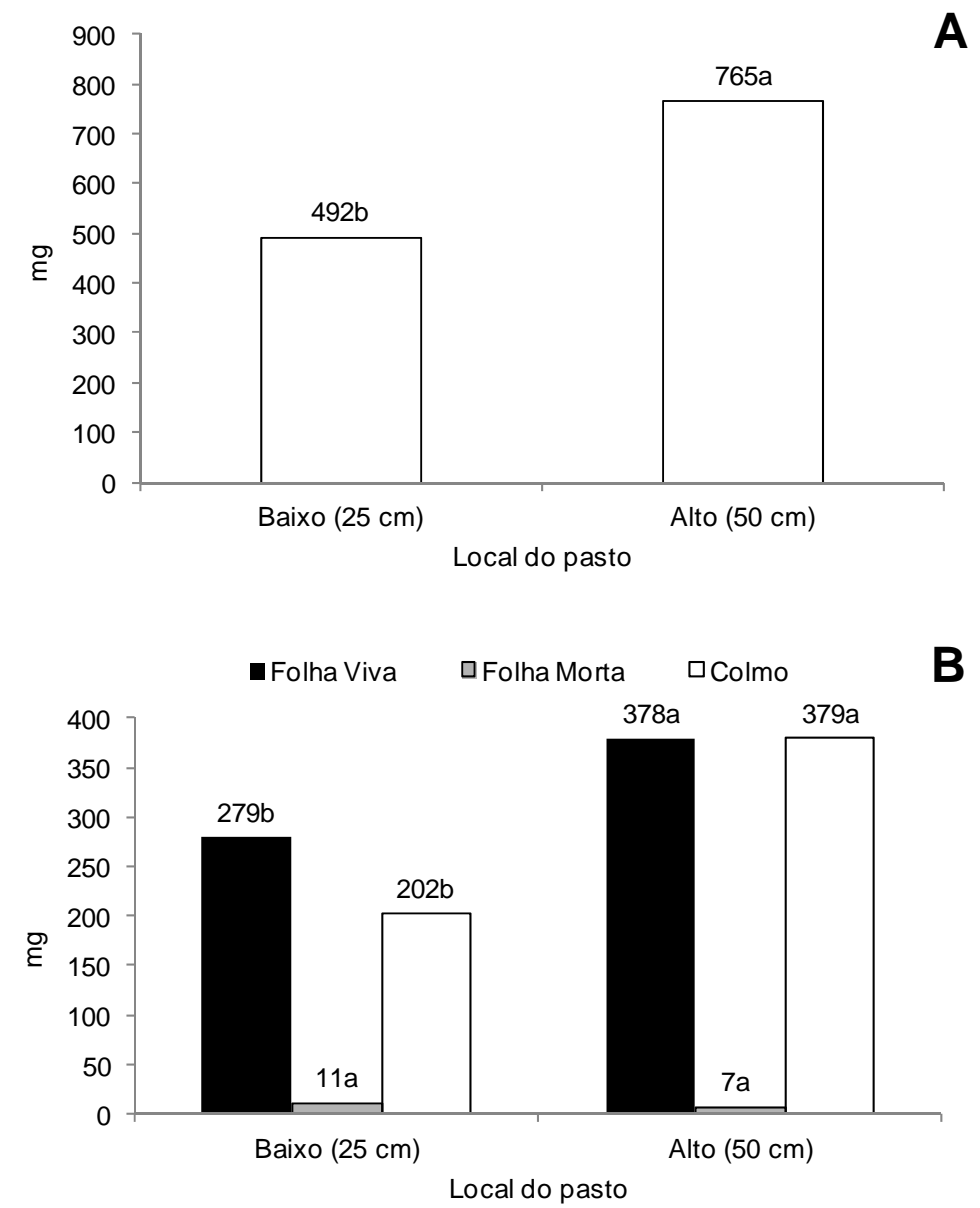

In each graph, means followed by the same letter did not differ by $\mathrm{F}$ test $(\mathrm{P}>0.05)$.

Figure 3. Weight (A) and mass of the morphological components (B) of young tillers of Brachiaria brizantha cv. Marandu in low and high places of the same pasture.

The mass of the morphological components of the plants (living leaf and stem) usually follows the same pattern of response of the dimensions of these organs, ie, the 
longer the plant organs, the greater the mass of the organs. Possibly, the greater shading and consequent greater light competition in the high pasture site promoted the extension of the tiller stem. In fact, both stem and leaf blades presented longer lengths, as already discussed.

The individual weight of the tiller was higher in the high site than in the low site (Figure 3A), because the taller plants remain longer with a leaf area index (LAI) close to the critical one, from which competition for light in the canopy. In this condition, the stem elongation process is accentuated to expose the new leaves in the upper region of the canopy, where the luminosity is greater. The stem length results in higher tiller weight in plants with higher height (SBRISSIA et al., 2010), justifying the greater weight of young tillers in the high grass. The leaf/stem ratio was lower in the tiller from the high site, compared to the low site tiller (Figure 4).

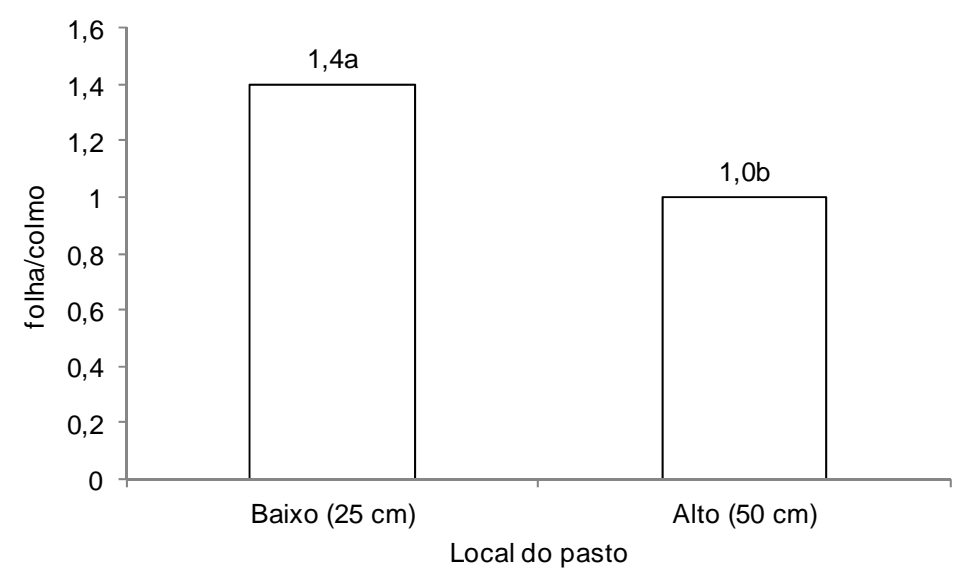

Means followed by the same letter did not differ by $F$ test $(\mathrm{P}>0.05)$.

Figure 4. Leaf/stem relationship of Brachiaria brizantha cv. Marandu tiller in low and high places of the same pasture.

The young tillers located in the high site had longer leaves and stems than the tillers from the low site (Figure 2A), but as the stem density is greater than the leaf density, reduction of the leaf/stem ratio occurred.

The data presented allow us to infer that the adoption of a management that results in great variability in the height of the canopy, with very high plants in the pasture, can damage the structure and the 
nutritive value of the pasture, since the young tillers that form in this place have smaller leaf/stem ratio (Figure 4). In addition, a high canopy can impair tillering (Figure 1C).

The results also indicate that the canopy structure, characterized by differences in height, forage mass and number of tillers (Figure 1), modifies the morphology of young tillers (Figures 2 to 4). This response pattern is probably mediated by the variable microclimate, which can be expressed by variations in temperature, humidity, ventilation, and brightness between the different canopy structures (high and low). In addition, these responses are an expression of the phenotypic plasticity of the marandu palisadegrass, which adjusts its developmental form and, in effect, modifies its morphology to better adapt to variations in the environment.

\section{Conclusion}

In the same pasture, the young tillers from tall plants of Brachiaria brizantha cv. Marandu have larger organs than those from the lower plant.

\section{References}

BULLOCK, J.M.; MORTIMER, A.M.; BEGON, M. Physiological integration among tillers of Holcus lanatus: age dependence and response to clipping and competition. New Phytologist, v. 128, p. 737-747, 1994.

https://doi.org/10.1111/j.1469-8137.1994.tb04037.x DEREGIBUS, V.A., SANCHEZ, R.A., CASAL, J.J. Effects of light quality on tiller production in Lolium spp. Plant Physiology, v.72, p.900-912, 1983.

https://doi.org/10.1104/pp.72.3.900

FONSECA, L.; MEZZALIRA, J.C.; BREMM, C.; FILHO, R.S.A.; GONDA, H.L.; CARVALHO, P.C.F. Management targets for maximising the short-term herbage intake rate of cattle grazing in Sorghum bicolor. Livestock Science, Amsterdam, v.145, p. 205-211, 2012. https://doi.org/10.1016/j.livsci.2012.02.003 
JANK, L.; T.G.S., BRAZ; MARTUSCELLO, J.A. Gramíneas de clima tropical. In: REIS, R.A.; BERNARDES, T.F.; SIQUEIRA, G.R. (Ed.) Forragicultura: ciência, tecnologia e gestão dos recursos forrageiros. Jaboticabal: Gráfica Multiplex, 2014a, p. 109-124.

KÖPEN, W. Climatologia. Buenos Aires: Gráfica Panamericana, 1948. 478p.

LARA, M.A. S; PEDREIRA, C.G. S. Respostas morfogênicas e estruturais de dosséis de espécies de Braquiária à intensidade de desfolhação. Pesquisa Agropecuária Brasileira, Brasília, v.46, n.7, p.760-767, jul. 2011.

PAIVA, A. J.; SILVA, S. C.; PEREIRA, L. E. T.; GUARDA, V.D.; MESQUITA, P.; CAMINHA, F.O. Structural characteristics of tiller age categories of continuously stocked marandu palisade grass swards fertilized with nitrogen. Revista Brasileira de Zootecnia, v. 41, p. 24-29, 2012.

PEDREIRA, C.G.S.; MELLO, A.C.L.; OTANI, L. O processo de produção de forragem em pastagens. In: REUNIÃO ANUAL DA SOCIEDADE BRASILEIRA DE ZOOTECNIA, 38., 2001, Piracicaba. Anais... Piracicaba: ESALQ, 2001. p.772807.

SANTOS, M.E.R.; FONSECA, D.M.; GOMES, V.M.; SANTOS, A.L.; CASTRO, M.R.S.; ALBINO, R.L. Diversidade de perfilhos em pasto de Brachiaria decumbens manejado sob lotação contínua. Boletim de Indústria Animal, v. 68, p. 17-26, 2011.

SANTOS, M.E.R.; GOMES, V. M.; FONSECA, D. M. Fatores causadores de variabilidade espacial do pasto de capim-braquiária: manejo do pastejo, estação do ano e topografia do terreno. Bioscience Journal, v. 30, p. 210-218, 2014. 
SBRISSIA, A.F.; DA SILVA, S.C.; SARMENTO, D.O.L.; MOLAN, L.K.; ANDRADE, F.M.E.; GONÇALVES, A.C.; LUPINACCI, A.V. Tillering dynamics in palisadegrass swards continuously stocked by cattle. Plant Ecology, v.206, p.349 - 359, 2010. https://doi.org/10.1007/s11258-009-9647-7SKINNER, R.H., NELSON, C.J. Elongation of the Grass leaf and its relationship to the phyllochron. Crop Science, v.35, n.1, p.4-10.1995.

VILELA, H.H.; SOUSA, B.M.L.; SANTOS, M.E.R.; SANTOS, A.L.; SILVA, N.A.M.; NASCIMENTO JUNIOR, D. Characterization of tillers of piata palisade grass deferred in the fall with varying heights and deferment periods. Acta Scientiarum. Zootechny, v. 35, p. 21-27, 2013. 